\title{
United Nation Bodies (2020)
}

\author{
Emanuele Sommario*
}

\section{Introduction}

This section analyses developments relevant to disaster law which occurred within generalist and specialised United Nations (UN) bodies during the course of 2020 . In particular, it will address 1) the adoption by the UN Security Council (SC) of Resolution $253^{1}$ on the COVID-19 pandemic, through which the Council has for the first time called for a global ceasefire in connection with an international health emergency; 2) the discussion within the Sixth Committee of the UN General Assembly (GA) on the 2016 Draft Articles (DAs) prepared by the International Law Commission (ILC) on the protection of persons in the event of disasters; and 3) the adoption by UNGA of Resolution 75/216 on 'Disaster Risk Reduction'. All of the documents analysed provide interesting insights on how the COVID-19 pandemic has impacted the practice of states and international organizations which have had to confront this formidable calamity.

On 1 July 2020, the UNSC unanimously adopted Resolution 2532 (2020) on the effects of the COVID-19 pandemic across the world and its impact on international peace and security. ${ }^{2}$ The adoption of the Resolution was the result of a lengthy and difficult process marked by frictions between the United States and China over the origins of the virus and by the collapse of the relationship between the World Health Organization (WHO) and the US administration,

* Associate Professor of International Law, Scuola Superiore Sant'Anna, Pisa.

1 UNSC, Resolution 2532 (2020) on cessation of hostilities in the context of the coronavirus disease (COVID-19) pandemic, 1 July 2020. Due to the restrictions introduced to tackle the pandemic, the resolution was adopted following a special written voting procedure described in a letter of the President of the SC, UN Doc S/2020/2532, 31 March 2020.

2 A second resolution on the topic was adopted by the Council in early 2021, reiterating its request for a general and immediate cessation of hostilities in all situations on its agenda and demanding that all parties to armed conflicts engage immediately in a durable, extensive and sustained humanitarian pause to facilitate the distribution of CoviD-19 vaccinations in areas of armed conflict. See UNSC, Resolution 2562 (2021), 21 February 2021. 
which led to disagreements on whether to mention the wHO in the resolution. ${ }^{3}$ The outcome was a brief and (in many respects) unsatisfactory text, marked by a number of compromises. ${ }^{4}$

\subsection{The Lead-up to Resolution 2532 (2020) and Its Contents}

The adoption of the Resolution was preceded by intense activity on the topic by other UN organs. On 30 January 2020, the COVID-19 outbreak was declared a 'public health emergency of international concern' (PHEIC) by the DirectorGeneral of the WHO in accordance with Art. 12.1 of the International Health Regulations (IHR, 2005). ${ }^{5}$ On 23 March 2020, UN Secretary-General Antonio Guterres called for an 'immediate global ceasefire' in order 'to put armed conflict on lockdown' and focus energies on tackling the pandemic. ${ }^{6}$ The underlying assumption was that conflicts facilitated the spread of the disease and, at the same time, hampered local and international response capacities. On 2 April 202O, the UNGA followed the lead of the Secretary-General by voting on a resolution restating the need for global solidarity and multilateral cooperation to fight COVID-19. ${ }^{7}$ The adoption of two additional resolutions ${ }^{8}$ stressed the importance of a collective and coordinated response to the pandemic. The activism of the Secretary-General and of the GA was in sharp contrast with the wavering attitude of the sc.

3 On the resolution's negotiation process, see Louis Balmond, 'Le Conseil de Sécurité des Nations Unies face à la pandemie de Covid-19: pourquoi ce silence?', in Regards de chercheurs - Université de Toulon, 5 July 2020, 4-5 available at <https://www.univ-tln.fr/ IMG/pdf/louis-balmond.pdf>, last accessed (as any subsequent URL) on 14 August 2021.

4 See Maurizio Arcari, 'Some thoughts in the aftermath of Security Council Resolution 2532 (2020) on Covid-19' (2020) 7 Quest. Int. Law 6o.

5 WHO, International Health Regulations (2005), wHA 58.3, 3rd edn., 2005. According to Art. 1 of the IHR, a PHEIC is 'an extraordinary event which is determined (...) (i) to constitute a public health risk to other States through the international spread of disease and (ii) to potentially require a coordinated international response'. States have a legal duty to promptly respond to a PHEIC.

6 United Nations, Secretary-General's Appeal for Global Ceasefire, Statements (23 March 2020) <https:/www.un.org/sg/en/content/sg/statement/202O-O3-23/secretary-generals-appeal -for-global-ceasefire $>$.

7 UNGA, 'Global solidarity to fight the coronavirus disease 2019 (COVID-19)', UN Doc A/ RES/74/270, adopted on 2 April 2020 (3 April 2020).

8 UNGA, 'International cooperation to ensure global access to medicines, vaccines and medical equipment to face COVID-19', UN Doc A/RES/74/274, adopted on 20 April 2020 (21 April 202O); UNGA, 'Comprehensive and coordinated response to the coronavirus disease (COVID-19) pandemic', UN Doc A/Res/74/306, adopted on 11 September 2020 (15 September 2020); UNGA, 'United response against global health threats: combating COVID 19', UN Doc A/ RES/74/307, adopted on 11 September 2020 (15 September 2020). 
In the text of Resolution 2532 (2020), the UNSC determined that 'the unprecedented extent of the CoviD-19 pandemic is likely to endanger the maintenance of international peace and security' and demanded from all parties to armed conflicts on its agenda a 'general and immediate cessation of hostilities'. ${ }^{9}$ The Council then called upon all parties to armed conflicts (including those with which it had not been seized) 'to engage immediately in a durable humanitarian pause for at least go consecutive days, in order to enable the safe, unhindered and sustained delivery of humanitarian assistance, provisions of related services by impartial humanitarian actors', in accordance with humanitarian principles. ${ }^{10}$ This is the first time the UNSc has called for a global ceasefire in connection with an international health emergency. ${ }^{11}$ However, not all conflict situations were covered by the Council's appeal, as OP 3 restricted the scope of the global ceasefire by providing that it should not apply to armed operations carried out against ISIL, Al-Qaeda and other terrorist entities designated by the Council.

This is not the first occasion in which the Council has dealt with the real or potential impact of contagious diseases on international peace and security. In 2000, the Council adopted Resolution 1308 (2000), ${ }^{12}$ which acknowledged that the HIV/AIDS pandemic represented a 'potential risk to stability and security', especially in consideration of the possible adverse impact of the disease on international peacekeepers. Some 14 years later, in response to the Ebola crisis in West Africa, the SC adopted Resolution 2177 (2014), which recognised that the outbreak was 'undermining the stability of the most affected countries concerned' and that it 'may lead to further instances of civil unrest, social tensions and a deterioration of the political and security climate', thereby leading the Council to characterise the outbreak as 'a threat to international peace and security'. ${ }^{3}$

$9 \quad$ UNSC (n 1$)$ operative paragraph (OP) 1.

$10 \quad$ Ibid., op 2.

11 Stefania Negri, 'Introductory Note to United Nations Security Council Resolution 2532', 6o International Legal Materials 26.

12 UNSC, Resolution 1308 (2000) on responsibility of the Security Council in the Maintenance of International Peace and Security: HIV/AIDS and International Peace-keeping Operations, UN Doc S/200o/1308, 17 July 2000.

13 UNSC, Resolution 2177 (2014) on the outbreak of the Ebola virus in and its impact on West Africa, UN Doc S/2014/2177, 14 September 2014. For a comment on the implication of the resolution, see Pia Acconci, 'The Reaction to the Ebola Epidemic within the United Nations Framework. What Next for the World Health Organization?' (2014) 18 Max Planck Yearbook of United Nations Law 405. 


\section{$2.1 \quad$ Legal Nature of Resolution 2532 (2020)}

With respect to the qualification of the situation in Resolutions 2532 (2020), the question was asked as to why the Council did not revert to the solution adopted with respect to the Ebola outbreak, which was openly referred to as a threat to peace with a clear reference to Chapter VII of the UN Charter. Instead, the resolution used 'softer' language, almost literally reproducing the terms of Article 33(1) of the UN Charter which triggers UNSC action in the field of the peaceful settlement of disputes under Chapter VI. ${ }^{14}$ As is known, Chapter VII grants the SC enforcement powers to maintain international peace and security, in contrast to Chapter VI in which only recommendations that are not legally binding on either member states or on other actors can be adopted..$^{15}$

This is the reason some commentators have suggested that the call for a global ceasefire does not impose on its addressees a legally binding obligation to comply with it. ${ }^{16}$ This interpretation appears to be supported by the exhortative terms used in the resolution's operative paragraphs, a feature which appears to be in line with the dispute-resolution functions that the Sc has under Chapter vI. ${ }^{17}$ While it is true that even resolutions based on Chapter VI may under certain circumstances give rise to legally binding obligations, ${ }^{18}$ it must be noted that such an intention does not explicitly emerge from the text of Resolution 2532 (2020) and seems to be at odds with its difficult negotiating history. Moreover, in its 2021 resolution devoted to the coviD-19 emergency, the Council 'expressed concern' that the call for a general and immediate cessation of hostilities which was contained in its Resolution 2532 (2020) had not been fully heeded, ${ }^{19}$ but it decided not to adopt any enforcement measure to

14 Ilja Richard Pavone, 'Security Council Resolution 2532 (2020) on Covid-19 A Missed Opportunity?' EsIL Reflections Covid-19 Series, Vol. 9, Issue 5, 8 February 2021; Arcari (n 4) 68.

15 Michael Wood, 'United Nations, Security Council' in Max Planck Encyclopeida of Public International Law <www.mpepil.com > (last updated in 2007).

16 Erin Pobjie, 'Covid-19 as a threat to international peace and security: The role of the UN Security Council in addressing the pandemic', EJIL Talk, 27 July 2020, <ejiltalk.org/covid19-as-a-threat-to-international-peace-and-security-the-role-of-the-un-security-councilinaddressing-the-pandemic/>; Arcari (n 4) 65 .

17 Anne Peters, 'Die Pandemie und das Völkerrecht', Max Planck Institute for Comparative Public Law \& International Law, Research Paper No. 2021-03, 9 February 2021, 4.

18 Rosalyn Higgins, 'The Advisory Opinion on Namibia: Which UN Resolutions are Binding Under Article 25 of the Charter?' (1972) 21 International and Comparative Law Quarterly 270. See also Negri (n 11) 26, contending that the lack of reference to Chapter VII would not deprive the Council's demands of their mandatory nature.

19 UNSC, Resolution 2562 (n 2), third preambular paragraph. See also 'How COVID-19 gave peace a chance, and nobody took it', The Economist, 5 May 2020, <https://www.economist .com/international/2020/05/o5/how-covid-19-gave-peace-a-chance-and-nobody -took-it>. 
address the issue. This might constitute another indicator that Resolution 2532 (2020) had no binding force.

\subsection{Final Considerations}

One striking element in the resolution at hand is the UNSC's decision to exclude the military operations in which the Islamic State, Al Qaeda and other terrorist groups are involved from its call for a global ceasefire. The United States and Russia were clearly concerned about the ramifications of a cessation of hostilities for their respective counterterrorist operations in the Middle East. However, it is not entirely clear why a humanitarian pause should not equally apply to situations (such as the ones prevailing in Syria or Iraq) in which the civilian population has endured serious consequences from the COVID-19 pandemic. ${ }^{20}$ In addition, groups excluded from the effects of the ceasefire have used the COVID-19 crisis to reassert existing anti-Western narratives, and their explicit exclusion from Resolution 2532 (2020) appears to have bolstered the legitimacy of these claims. ${ }^{21}$

At the same time, it must be highlighted that Resolution $253^{2}$ (2020) is part of a recent trend by the SC to deal with non-conventional threats to peace and security, adopting an evolutionary interpretation of the notion of threat under Article 39 of the UN Charter 'in the light of new economic, social, humanitarian, and ecological challenges.'22 The growing role of the Council in tackling non-traditional threats might also open the door to a more interventionist approach in other disaster prevention and response activities, especially in light of the rising awareness of the effects of climate change as a key driver of disasters. ${ }^{23}$ It should also be borne in mind that the Council has already displayed a willingness to intervene in the aftermath of natural disasters. In 2010, it adopted Resolution $1908(2010)^{24}$ in response to a devastating earthquake that killed almost 30o,ooo people in Haiti. The decision expanded the mandate of the UN Stabilization Mission in Haiti (MINUSTAH), asking it 'to support the immediate recovery, reconstruction and stability efforts'. ${ }^{25}$ Further interventions by the Council in the wake of egregious catastrophes would not be

20 WFP, Syria - Socio-Economic Impacts of the COVID-19 Pandemic, October 2020, <https:// docs.wfp.org/api/documents/WFP-oooo120o93/download/>.

21 Tyler Jess Thompson, 'Searching for COVID-19 Ceasefires: Conflict Zone Impacts, Needs, and Opportunities' (2020) US Institute of Peace, Special Report N. 480, 15.

22 Stefania Negri (n 11) 24.

23 Mark Nevitt, 'Is Climate Change a Threat to International Peace and Security?' (2021) 42 Michigan Journal of International Law 527.

24 UNSC, Resolution 1908 (2010) on increasing the overall force levels of the UN Stabilization Mission in Haiti to support the immediate recovery, reconstruction and stability efforts, UN Doc S/2010/1908, 19 January 2010. 
unexpected, although the COVID-19 emergency has evidenced the limits of its action and its inability to insulate its activities from geopolitical dynamics. ${ }^{26}$

\section{The Debate within the GA's Sixth Committee on the ILC's Draft Articles on the 'Protection of Persons in the Event of Disasters'}

In 2016, at its seventy-first session, the GA decided to include in the provisional agenda of its seventy-third session an item entitled 'Protection of persons in the event of disasters' and it invited governments to submit comments concerning the recommendation by the Commission to elaborate a convention on the basis of the draft articles on the topic that the ILC had just presented. ${ }^{27}$ In 2018, at its seventy-third session, the GA allocated the item to its Sixth Committee (the primary forum for the consideration of legal questions in the GA) where statements were made by 24 delegations. ${ }^{28}$ The Assembly then decided to include the item in the provisional agenda of its seventy-fifth session, scheduled for $202 \mathrm{O}^{29}$

The Sixth Committee considered the item at its 17th, 18 th and 19th meetings between 11 and 19 November 2020. The members had before them the report of the UN Secretary-General submitted to the GA at its seventy-fifth session ${ }^{30}$ which contained written comments that had been received from Colombia, Cuba, El Salvador, Italy, Japan and Turkey. During the debate, statements were made by the representatives of 33 States (with Sweden also speaking on behalf of the Nordic countries, i.e. Norway, Finland, Iceland and Denmark). The discussion was informed by the recognition that - as the world continued to face a growing number of disasters - the CoviD-19 pandemic had exposed major gaps in the international legal order. This appears to have prompted a new awareness by Member States of the importance of achieving international cooperation to prevent and address natural and human-made disasters.

26 Bruno Charbonneau, 'The COVID-19 test of the United Nations Security Council', (2021) 76 International Journal 6.

27 UNGA, 'Protection of Persons in the Event of Disaster', UN Doc. A/REs/71/141, adopted on 13 December 2016 (19 December 2016) OP 2.

28 UNGA, 'Sixth Committee - Summary record of the 31st meeting' (1 November 2018) UN Doc A/C.6/73/sR.31. For a summary of the debate, see Emanuele Sommario, 'United Nation Bodies (2018)' (2019) 1 Yearbook of International Disaster Law 309-311.

29 UngA, 'Protection of Persons in the Event of Disaster', UN Doc. A/REs/73/209, adopted on 2o December 2018 (14 January 2019) OP 4.

3o Report of the Secretary-General, Protection of persons in the event of disasters, UN Doc A/75/214, adopted on 21 July 2020. 
Indeed, the majority of the delegations welcomed further discussion on the DAs and expressed appreciation for the work of the ILC and the Special Rapporteur on the topic, displaying a more open approach to the possibility of adopting a binding convention. Bangladesh stressed the importance of a globally accepted legal protection regime, which would 'facilitate an effective and timely response to disasters, strengthen disaster risk reduction efforts, promote the rights and dignity of affected persons and address their need for assistance. ${ }^{31}$ According to the Philippines, it is important to learn the lessons of the COVID-19 pandemic regarding the need for a prevention-focused, forward-looking and multilateral approach to disaster risk reduction, and the Committee 'should consider the elaboration of a binding legal instrument on the basis of the Commission's work' ${ }^{32}$ Similar positions were expressed by El Salvador, ${ }^{33}$ Sierra Leone, ${ }^{34}$ Sudan, ${ }^{35}$ Portugal, ${ }^{36}$ Jamaica, ${ }^{37}$ Italy, ${ }^{38}$ Cuba, ${ }^{39}$ Thailand ${ }^{40}$ Colombia, ${ }^{41}$ Nigeria, ${ }^{42}$ Brazil ${ }^{43}$ and Tonga. ${ }^{44}$

Other delegations seemed to be more wary vis-à-vis the conclusion of a treaty. Singapore, for instance, noted the divergence of views on future action but 'looked forward to further discussions on whether a convention should be elaborated on the basis of the draft articles' ${ }^{\prime 5}$ The Nordic countries recognised the importance of further strengthening international cooperation, disaster relief and the humanitarian assistance system and were 'open to discussing the advantages and disadvantages of elaborating an international convention on

31 UNGA, 'Sixth Committee - Summary record of the 17th meeting' (11 November 2020), UN Doc. A/C.6/75/SR.17, 3o November 2020, 10.

32 Ibid., 11.

33 Ibid.

$34 \quad$ Ibid., 12.

35 Ibid., 13.

$36 \quad$ Ibid., 14.

37 Ibid.

$38 \quad$ Ibid., 15 .

39 The Cuban representative, however, pointed out that he did not consider the DAs 'an exercise in the codification of customary international law', adding that they 'rather reflected progressive development', ibid., 16.

$40 \quad$ Ibid., 16.

41 UNGA, 'Sixth Committee - Summary record of the 18th meeting' (13 November 2020) UN Doc. A/C.6/75/sR.18, 16 December 2020, 2.

42 Ibid., 3.

43 However, according to the Brazilian delegation, the regulation of natural and humanmade disasters should be clearly distinguished, as it would be 'difficult to cover vastly different scenarios in a single instrument', ibid., 4 .

44 Ibid., 5 .

45 UNGA (n 31$) 10$. 
the basis of the draft articles' 46 Similarly, Egypt contended that 'more consultations were needed between Member States to build the necessary consensus before any decision was taken on the next steps regarding the draft articles under discussion'.47 The delegations of Brunei ${ }^{48}$ and Japan ${ }^{49}$ expressed comparable positions. China expressed an ambivalent stance, as it was in favour of a continued multilateral dialogue on the topic but stressed that 'a better balance of rights and obligations between affected States and assisting actors' should be achieved. ${ }^{50}$

Finally, a few states expressed discontent at the hypothesis of a treaty to address disaster prevention and response issues. Russia lamented a lack of safeguards for the principle of state sovereignty, adding that it would be 'premature to consider the adoption of a legally binding instrument at the current time. ${ }^{51}$ Israel maintained that the DAs 'should be formulated as guidelines or principles for voluntary international cooperation efforts',52 and that the topic should not be considered in terms of rights and duties. The delegations of Malaysia, ${ }^{53}$ Vietnam $^{54}$ and the United States of America were also against the development of a binding instrument..$^{55}$

Interestingly, a number of delegations stressed the fact that the Covid-19 pandemic should be classified as a disaster as defined in DA $3 .{ }^{56}$ Statements to that effect were made by Egypt, ${ }^{57}$ Portugal, ${ }^{58}$ Colombia, ${ }^{59}$ Iran ${ }^{60}$ China $^{61}$

46 Ibid., 9 .

$47 \quad$ Ibid., 13.

48 Ibid.

49 Ibid., 15.

5 O UNGA (n 41$) 3$.

51 UNGA (n 31) 14. The Russian delegation also severely criticized the DAs, rather cryptically stating that they 'did not constitute codification or progressive development of international law in that area', ibid.

$5^{2} \quad$ UNGA (n 41$) 2$.

53 UNGA (n 31$) 16$.

$54 \quad$ UNGA $(\mathrm{n} 41) 3$.

55 Ibid., 5 .

56 According to Article 3(a) of the ILC DAs, 'disaster' means 'a calamitous event or series of events resulting in widespread loss of life, great human suffering and distress, mass displacement, or large-scale material or environmental damage, thereby seriously disrupting the functioning of society', see ILC, 'Report of the International Law Commission: Sixty-Eighth Session (2 May-10 June and 4 July-12 August 2016)' UN Doc A/71/10, 14.

57 UNGA (n 31$) 13$.

58 Ibid., 14.

$59 \quad$ UNGA (n 41) 2.

6o Ibid.

61 Ibid., 3. 
and Nigeria. ${ }^{62}$ The characterisation of the pandemic as a disaster is in line with the broad definition provided in the DAs, which gives emphasis to the consequences of an event, rather than its formal classification, as the most important feature in determining if a given hazard falls within the scope of the DAS. In addition, this stance helps to clarify said scope and clearly place pandemics within the coverage of the Articles, since neither their text nor the related commentaries include an explicit reference to the notion. ${ }^{63}$

During the discussion, a proposal was made by the delegation of Colombia to defer the consideration of the issue to the seventy-sixth session of the Assembly. No objections were raised to the proposal and the topic will thus be discussed by the Sixth Committee in 2021, when it is expected to adopt a draft resolution on the issue. ${ }^{64}$

\section{$4 \quad$ Adoption by the GA of Resolution 75/216 on 'Disaster Risk Reduction'}

On 21 December 202O, the General Assembly adopted its yearly Resolution on Disaster Risk Reduction (DRR). ${ }^{65}$ In the document, the GA urges States to conduct inclusive and multi-hazard disaster risk assessments that consider the ramifications of the COVID-19 pandemic as well as climate change projections. The Resolution has the merit of using the coronavirus emergency to bring to the foreground the poor understanding of disaster risk as well as the interdependencies between different sectors of society in the areas of disaster prevention and response. The text stresses that the approach to DRR is still largely based on single-hazard tools and methodologies that are not always able to address economic, social, environmental and political drivers of disaster risk. Amongst the factors that prevent multidimensional risk assessments are the lack of a common methodology or terminology for the collection and analysis

\footnotetext{
$62 \quad$ Ibid.

63 Alp Ozturk, 'Covid-19: Just Disastrous or the Disaster Itself? Applying the ILC Articles on the Protection of Persons in the Event of Disasters to the Covid-19 Outbreak', 24 ASIL Insights, 24 April 2020, <https://www.asil.org/insights/volume/24/issue/6/covid-19-just -disastrous-or-disaster-itself-applying-ilc-articles $>$.

64 UNGA, 'Sixth Committee - Summary record of the 19th meeting' (19 November 2020), UN Doc. A/C.6/75/sR.19, 21 April 2021, 6-7.

65 UNGA, 'Disaster Risk Reduction', UN Doc A/Res/75/216, adopted on 21 December 2020 (23 January 2020).
} 
of disaster risk data across sectors and regions, as well as limited capacity and inadequate coordination among stakeholders. ${ }^{66}$

The Resolution was adopted without a vote, ${ }^{67}$ and thus no insights can be gained on possible criticalities within the text. It is worth noting, however, that the final version does not include the recommendation of the SecretaryGeneral who suggested that Member States should make DRR a legal obligation under national law. ${ }^{68}$ This is unfortunate, as the notion of a legally binding commitment to introduce and enforce regulations and standards in the area of DRR would clearly reduce the adverse consequences of disasters (and possibly avert many altogether) and also favour the emergence of relevant rules of general international law in the area.

66 Report of the Secretary-General, 'Implementation of the Sendai Framework for Disaster Risk Reduction 2015-2030', A/75/226*, 23 July 2020, 16.

67 UNGA, UN Doc A/75/PV.48, 21 December 2020, 12.

68 Report of the Secretary-General (n 66) 19. 